\title{
Middle East: trying to break down the barriers
}

\author{
Collaborations are welcome, but can science ever thrive while the conflict continues?
}

Sir - Your News Feature "Across the great divide" (Nature 425, 444-449; 2003) left me feeling despondent. As a Palestinian cell biologist, I am in favour of collaborations between open-minded Palestinian and Israeli scientists. This is for the benefit of both parties and will no doubt help in bridging the gap between the two nations. However, unless there is a huge investment in the Palestinian higher education system, this collaboration will continue to be on an unequal footing.

Israel has been illegally occupying and building settlements on Palestinian land since 1967. For many years, Israel has been subjecting the Palestinians to humiliation and collective punishment, including closing their schools and higher education institutions for long periods of time. This is done in the name of security although during the past three years, while Palestinian militants have killed some 800 Israelis, the Israeli army has killed more than 2,200 Palestinians.

A disturbing fact is that the vast majority of casualties on both sides are innocent civilians, including many children. In my opinion, the only way forward is to end the Israeli occupation of Palestinian land and relieve the daily suffering of ordinary Palestinians.

I am one of hundreds, perhaps thousands, of Palestinian scientists who are working abroad, waiting for the opportunity to go back to Palestine and serve science and education in our own homeland. We had a glimmer of hope with the Oslo agreements in 1996, and many Palestinian scientists returned at that time, but their dreams and lives were soon shattered by the current crisis.

A major obstacle to Palestinian scientists wishing to return home is the lack of infrastructure and funds for research at Palestinian institutions. Perhaps we should create more opportunities for Israeli scientists in Israel to collaborate with Palestinian scientists working in Europe or America, and wishing to return to Palestine in due course. This approach would be complementary to the existing local collaborations between Palestinian and Israeli institutions.

Bassam R. Ali

Molecular Cell Biology Section,

Division of Biomedical Sciences,

Faculty of Medicine, Imperial College London,

Exhibition Road, London SW7 2AZ, UK

\section{Middle East: a picture is worth a thousand words}

Sir - Nature has been careful to avoid taking a political stance in the IsraeliPalestinian conflict, and has taken a welcome position against the boycotting of Israeli scientists.

In this context, your News Feature "Across the great divide" (Nature 425,
444-449; 2003) was mostly a well-balanced presentation of a complex situation, but I found the choice of graphics quite perturbing. The photographs used to illustrate the News Feature included two of Israeli military activity and three of the security wall, one of which appeared on the front cover.

Although these photos were provided by news agencies, I question the selection. It might have been more realistic, for example, if the youth seen scaling the wall in the cover photograph had been armed. There was only a single photo of the Israeli side of the conflict - a bus that had been destroyed by a suicide bomber - and one showing Hamas supporters.

The article correctly points out how personal this conflict is. I myself have been at a number of funerals and condolence calls for victims of suicide attacks, and have narrowly escaped being a victim. Despite this, I still hope for a peaceful solution to the conflict.

I feel that despite its shortcomings, and its negative appearance in photographs, the security barrier remains the least violent way currently available to improve the security situation here.

A picture is worth a thousand words and Nature should be as careful in its choice of graphics as it is in its choice of words.

Joel Bigman

Address withheld by request

Haifa, Israel

\section{Timaeus's insight on the shape of the Universe}

Sir - With reference to the Letter to Nature"Dodecahedral space topology as an explanation for weak wide-angle temperature correlations in the cosmic microwave background" by J. P. Luminet et al. (Nature 425, 593-595; 2003), perhaps it is worth recalling that a similar intuition struck Timaeus of Locri 2,500 years ago.

Timaeus (fifth century BC) was a Pythagorean philosopher from Locri, in Magna Graecia, now southern Italy. He was also a mathematician and astronomer. Plato studied with him while he was visiting Magna Graecia, and later wrote a dialogue presenting Timaeus in discussion with Socrates.

Out of the five regular, or Platonic, solids (tetrahedron, octahedron, cube, icosahedron and dodecahedron), Plato tells how Timaeus thought of a mystical correspondence between the first four and the four natural 'elements' (fire, air, earth and water). As for the dodecahedron, the fifth regular solid, Timaeus regarded it as a shape that envelopes the whole Universe.

Claudio Giomini

Dipartimento ICMMPM, via del Castro

Laurenziano 7, I-00161 Rome, Italy

\section{Chemists enthusiastic to embrace change}

Sir - Your coverage of the recent American Chemical Society meeting in New York ("Chemists seek image overhaul," Nature 425, 227; 2003 ) described a symposium that was barely recognizable to those participating.

Far from involving an "image overhaul", the discussion centred on reinventing chemistry education so that it better fits the science of today.

The goal is to improve the training of scientists who will be working in an increasingly interdisciplinary environment.

By quoting comments that were made on the periphery of the discussion, your News story did not convey the enthusiasm expressed by many members for embracing change.

Indeed, the symposium - and the major conference that preceded it - are merely the first steps in what will, we feel, be a sea change in science education that will involve all our members.

Daryle Busch, Eli Pearce

American Chemical Society, 1155 16th Street NW, Washington DC 20034, USA

\section{correspondence}

Contributions to Correspondence may be submitted to corres@nature.com. They should be no longer than 500 words, and ideally shorter. Published contributions are edited. 